\title{
Maribacter stanieri sp. nov., a marine bacterium of the family Flavobacteriaceae
}

Correspondence

Olga I. Nedashkovskaya

olganedashkovska@piboc.dvo.ru

or olganedashkovska@gmail.com
Olga I. Nedashkovskaya, ${ }^{1}$ Seung Bum $\mathrm{Kim}^{2}$ and Valery V. Mikhailov ${ }^{1}$

\author{
${ }^{1}$ Pacific Institute of Bioorganic Chemistry of the Far-Eastern Branch of the Russian Academy of \\ Sciences, Pr. 100 Let Vladivostoku 159, 690022, Vladivostok, Russia \\ ${ }^{2}$ Department of Microbiology, Chungnam National University, 220 Gung-dong, Yusong, Daejon \\ 305-764, Republic of Korea
}

The genus Maribacter was created by Nedashkovskaya $e t$ al. (2004) to accommodate aerobic and obligatory marine bacteria that move by gliding and form a distinct phylogenetic lineage within the family Flavobactericeae (Bernardet et al., 2002). The description of the genus was recently emended because it was found that some newly isolated strains did not require $\mathrm{Na}^{+}$ions for growth (Barbeyron et al., 2008). At the time of writing, the genus Maribacter comprised eight recognized species (Barbeyron et al., 2008; Cho et al., 2008; Nedashkovskaya et al., 2004, 2007; Yoon et al., 2005). Most species of the genus Maribacter are free-living organisms, while strains of two species are associated with green and red algae. Environmental clones identified as belonging to the genus Maribacter have been obtained from seawater, sea ice and algae collected from the subantarctic regions of Argentina, from the Inland Sea of Japan and from the north-western Mediterranean Sea (Prabagaran et al., 2007; Hamasaki et al., 2007; Agogué et al., 2005).

In a course of a survey of the biodiversity of coastal microbial communities inhabiting the Sea of Japan (also known as the East Sea), we discovered two novel, yellow pigmented isolates. A study of their phylogenetic and phenotypic characteristics revealed that strains KMM 6025 and KMM $6046^{\mathrm{T}}$ belonged to the family Flavobacteriaceae and clustered with the species of the genus Maribacter, amongst which they formed a distinct lineage.

The GenBank/EMBL/DDBJ accession number for the 16S rRNA gene sequences of Maribacter stanieri KMM 6025 and $\mathrm{KMM} 6046^{\top}$ are EF536746 and EU246691, respectively.
Strain KMM 6025 was isolated from a seawater sample, while strain $\mathrm{KMM} 6046^{\mathrm{T}}$ was obtained from the green alga Ulva fenestrata collected from the Gulf of Peter the Great of the Sea of Japan. For strain isolation, $0.1 \mathrm{ml}$ seawater or algal tissue homogenate were transferred onto plates of marine agar 2216 (Difco). After primary isolation, the strains were cultivated at $28{ }^{\circ} \mathrm{C}$ on marine agar (Difco) and stored at $-80{ }^{\circ} \mathrm{C}$ in marine broth (Difco) supplemented with $20 \%(\mathrm{v} / \mathrm{v})$ glycerol.

The phylogenetic position of strains KMM 6025 and KMM $6046^{\mathrm{T}}$ was determined from their almost-complete 16S rRNA gene sequences (1434 and $1432 \mathrm{bp}$, respectively). Genomic DNA extraction, PCR and sequencing of $16 \mathrm{~S}$ rRNA genes were performed by using previously described procedures (Cho et al., 2006). The sequences obtained were aligned with those of representative members of selected genera belonging to the family Flavobacteriaceae by using PHYDIT version 3.1 (http://plaza.snu.ac.kr/ jchun/phydit/). Phylogenetic trees were inferred by using appropriate programs from the PHYLIP package (Felsenstein, 1993). Phylogenetic distances were calculated from the two-parameter model (Kimura, 1980) and the trees were constructed on the basis of the neighbour-joining (Saitou \& Nei, 1987), maximum-likelihood (Felsenstein, 1993) and maximum-parsimony (Kluge \& Farris, 1969) algorithms. Bootstrap analysis was performed with 1000 resampled datasets, using the SEQBOOT and CONSENSE programs of the PHYLIP package.

Phylogenetic analysis of the almost-complete 16S rRNA gene sequences of strains KMM 6025 and KMM $6046^{\mathrm{T}}$ 
$\underline{0.01}$

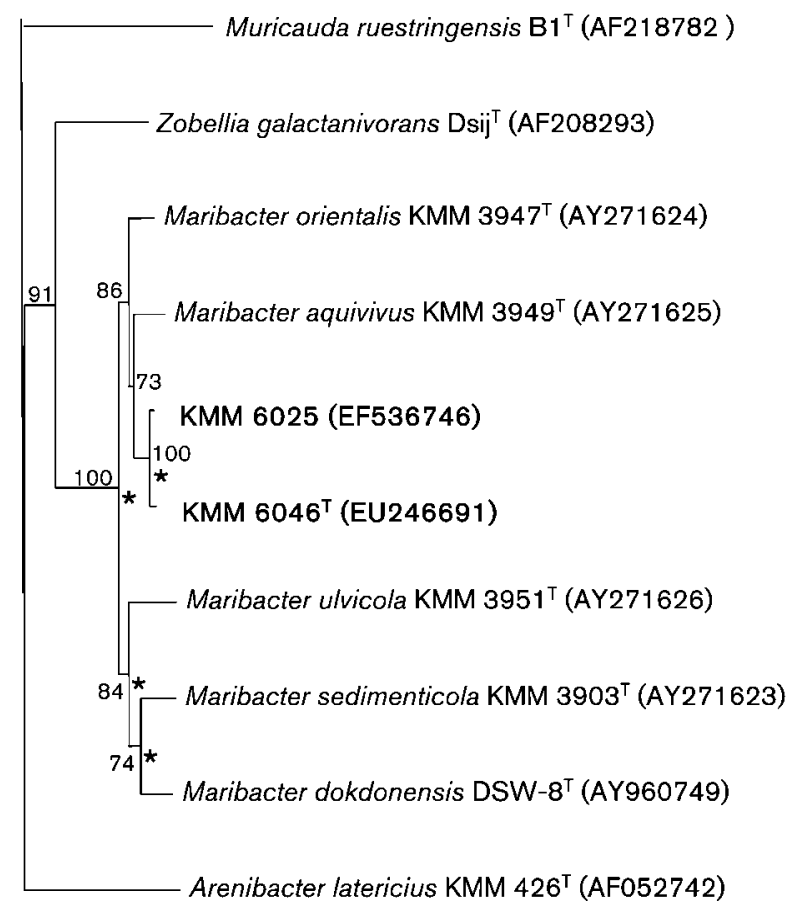

Fig. 1. Phylogenetic tree based on the 16S rRNA gene sequences of species of the genus Maribacter and related taxa. The tree was constructed using Kimura's two-parameter model and the neighbour-joining algorithm. Asterisks indicate branches that were also recovered in the maximum-likelihood and maximumparsimony trees. The numbers at nodes indicate levels of the bootstrap support (\%). Bar, 0.01 nucleotide substitutions per position.

revealed that the strains formed a distinct evolutionary lineage within the genus Maribacter, a member of the family Flavobacteriaceae (Fig. 1). The nearest neighbours of the novel isolates were Maribacter aquivivus KMM $3949^{\mathrm{T}}$ (98.3-98.5\% sequence similatity) and Maribacter orientalis KMM $3947^{\mathrm{T}}(98.2-98.4 \%)$. Sequence similarities of strains KMM 6025 and KMM $6046^{\mathrm{T}}$ to other species of the genus Maribacter were in the range $96.3-97.9 \%$. The sequence similarity between the two strains studied was $99.6 \%$.

For determination of the DNA base composition, DNA was isolated following the technique of Marmur (1961) and the DNA $\mathrm{G}+\mathrm{C}$ content was determined by the thermal denaturation method (Marmur \& Doty, 1962). The DNA $\mathrm{G}+\mathrm{C}$ contents of KMM 6025 and KMM $6046^{\mathrm{T}}$ were 36.1 and $36.6 \mathrm{~mol} \%$, respectively. DNA-DNA hybridization was performed spectrophotometrically and initial renaturation rates were recorded as described by De Ley et al. (1970). The level of DNA-DNA hybridization between strains KMM 6025 and KMM $6046^{\mathrm{T}}$ was $96 \%$, demonstrating that the two novel isolates belonged to the same species according to the proposal of Wayne et al. (1987). The level of DNA-DNA reassociation between strain $\mathrm{KMM} 6046^{\mathrm{T}}$ and recognized species of the genus Maribacter ranged from 34 to $51 \%$. Based on these data, the new isolates can be affiliated to the genus Maribacter as a distinct and novel species.

Analysis of fatty acid methyl esters was carried out on cells grown on marine agar at $28{ }^{\circ} \mathrm{C}$ for $48 \mathrm{~h}$ according to the standard protocol of the Microbial Identification System (Microbial ID Inc.). The dominant fatty acids of strain KMM $6046^{\mathrm{T}}$ were iso- $\mathrm{C}_{15: 1} \mathrm{G}$, iso- $\mathrm{C}_{15: 0}, \mathrm{C}_{15: 0}$, iso$\mathrm{C}_{17: 1} \omega 9 c$, iso- $\mathrm{C}_{17: 0} 3-\mathrm{OH}$ and summed feature 3 , comprising $\mathrm{C}_{16: 1} \omega 7 c$ and/or iso- $\mathrm{C}_{15: 0} 2-\mathrm{OH}$ (Table 1).

The physiological and biochemical properties of strains KMM 6025 and KMM $6046^{\mathrm{T}}$ were tested as described by Nedashkovskaya et al. (2004, 2006). API 20E, API 20NE and API ZYM galleries (bioMérieux) were also used in accordance with the manufacturer's instructions.

Strains KMM 6025 and KMM $6046^{\mathrm{T}}$ were heterotrophic, aerobic, Gram-negative, yellow pigmented organisms that were motile by gliding. They demonstrated many features that are characteristic for representatives of the genus Maribacter (Table 1). However, strains KMM 6025 and KMM $6046^{\mathrm{T}}$ differed from their closest relatives, Maribacter aquivivus and Maribacter orientalis, by their maximum growth temperature, acetoin production, raffinose oxidation and utilization of mannitol and citrate (Table 2). Additional properties such as hydrolysis of Tweens 20 and 80, acid production from cellobiose, galactose, glucose, lactose, maltose, melibiose and sucrose also separated the novel isolates from Maribacter aquivivus. Strains KMM 6025 and KMM $6046^{\mathrm{T}}$ could also be separated from Maribacter orientalis on the basis of the maximum concentration of $\mathrm{NaCl}$ for growth, by its ability to reduce nitrate to nitrite, to oxidize and to utilize L-arabinose and the DNA G+C contents. Other trends that may help in the differentiation of the novel strains from recognized species of the genus Maribacter are shown in Table 2. The novel isolates demonstrated several differences from each other. Thus, KMM 6025 and KMM $6046^{\mathrm{T}}$ grow with $1-8$ and $0.5-6 \%$ $\mathrm{NaCl}$ and at temperatures of up to 33 and $35^{\circ} \mathrm{C}$, respectively. In contrast to strain KMM 6025, the type strain is able to hydrolyse DNA and to oxidize L-rhamnose.

In conclusion, the phylogenetic and phenotypic distinctiveness between strains KMM 6025 and KMM $6046^{\mathrm{T}}$ and other species of the genus Maribacter clearly indicated that they represent a novel species of the genus, for which the name Maribacter stanieri sp. nov. is proposed.

Originally, members of the genus Maribacter were described as bacteria that required $\mathrm{Na}^{+}$ions for growth (Nedashkovskaya et al., 2004). Recently, the genus description was emended because strains of a novel species, Maribacter forsetii, demonstrated weak growth on nutrient media containing no $\mathrm{NaCl}$ (Barbeyron et al., 2008). The inability of Maribacter strains to reduce nitrate to nitrite was also included in the emended description of the genus. Production of nitrate reductase by Maribacter forsetii and 
Table 1. Whole-cell fatty acid profiles (\%) of species of the genus Maribacter

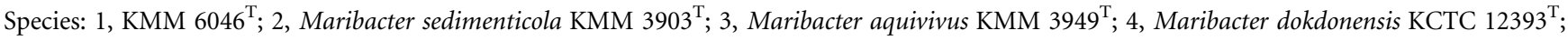
5, Maribacter forsetii KT02ds18-6 ${ }^{\mathrm{T}}$; 6, Maribacter orientalis $\mathrm{KMM} 3947^{\mathrm{T}} ; 7$, Maribacter polysiphoniae $\mathrm{KMM} 6151^{\mathrm{T}}$; 8, Maribacter ulvicola $\mathrm{KMM}$ $3951^{\mathrm{T}}$. Only those fatty acids amounting to $>1.0 \%$ in one of the strains listed are indicated. Summed feature 3 consisted of one or more of the following fatty acids which could not be separated by the Microbial Identification System: iso- $\mathrm{C}_{15: 0} 2-\mathrm{OH}$ and $\mathrm{C}_{16: 1} \omega 7 \mathrm{c}$. Summed feature 4 consisted of one of the following fatty acids: $\mathrm{C}_{17: 1}$ iso I and $\mathrm{C}_{17: 1}$ anteisoB. Data are taken from Barbeyron et al. (2008), Nedashkovskaya et al. (2004, 2007), Yoon et al. (2005) and this study.

\begin{tabular}{|c|c|c|c|c|c|c|c|c|}
\hline Fatty acid & 1 & 2 & 3 & 4 & 5 & 6 & 7 & 8 \\
\hline iso- $\mathrm{C}_{14: 0}$ & - & - & - & - & 0.4 & - & 1.4 & - \\
\hline $\mathrm{C}_{14: 1} \omega 5$ & - & - & 1.0 & - & - & - & - & 0.9 \\
\hline iso- $\mathrm{C}_{15: 0}$ & $10.4-14.0$ & 20.5 & 12.3 & $19.7-20.3$ & $11.9-12.5$ & 10.6 & 15.4 & 13.6 \\
\hline anteiso- $\mathrm{C}_{15: 0}$ & $2.4-2.5$ & 1.2 & 1.3 & $0.3-0.4$ & 1.0 & 2.3 & 7.6 & 1.9 \\
\hline $\mathrm{C}_{15: 0}$ & $6.1-9.9$ & 6.3 & 14.5 & $3.5-3.8$ & $14.7-15.5$ & 12.3 & 11.0 & 8.1 \\
\hline $\mathrm{C}_{15: 1} \omega 6 c$ & $1.6-2.1$ & 1.7 & 4.8 & 0.6 & 2.8 & 2.5 & 3.9 & 1.6 \\
\hline iso- $\mathrm{C}_{16: 1} \mathrm{H}$ & $0-0.2$ & - & - & - & $0.7-0.9$ & - & 1.4 & - \\
\hline iso- $\mathrm{C}_{16: 0}$ & $0.4-0.7$ & 1.1 & 0.7 & - & $1.6-1.7$ & 0.3 & 1.8 & 0.3 \\
\hline $\mathrm{C}_{16: 0}$ & 0.6 & 1.0 & 0.5 & $1.3-1.4$ & 1.0 & 1.2 & 1.0 & 1.0 \\
\hline iso- $\mathrm{C}_{17: 1} \omega 5 c$ & - & - & 1.4 & - & - & - & - & 1.2 \\
\hline $\mathrm{C}_{15: 0} 3-\mathrm{OH}$ & - & 2.4 & 2.3 & 1.4 & $1.4-1.5$ & 1.5 & 2.1 & 1.5 \\
\hline iso- $\mathrm{C}_{16: 0}-3 \mathrm{OH}$ & $0.7-0.9$ & 1.7 & 2.5 & $1.0-1.1$ & $5.9-6.8$ & 2.1 & 9.1 & 1.7 \\
\hline $\mathrm{C}_{16: 0} 3-\mathrm{OH}$ & $0.9-1.2$ & 2.2 & 2.9 & $5.4-5.5$ & $1.8-2.2$ & 3.0 & 0.5 & 3.7 \\
\hline iso- $\mathrm{C}_{17: 0} 3-\mathrm{OH}$ & $11.1-11.9$ & 20.4 & 11.6 & $28.6-29.2$ & $18.3-19.7$ & 18.8 & 7.2 & 14.5 \\
\hline $\mathrm{C}_{17: 0} 2-\mathrm{OH}$ & $0.3-0.4$ & - & - & - & $0-0.3$ & - & 1.4 & - \\
\hline iso-C18: 1 & - & - & - & - & - & 2.4 & - & - \\
\hline Summed feature 3 & $11.4-14.8$ & 5.8 & 12.9 & $8.4-8.6$ & $10.1-11.0$ & 11.4 & 10.1 & 12.2 \\
\hline Summed feature 4 & $0-1.2$ & - & - & - & - & - & - & - \\
\hline
\end{tabular}

by the type strains of other Maribacter species was tested only by using the API 20NE gallery but it is already known that the API system gives negative results for flavobacteria and therefore this phenotypic feature needs to be checked using other classical methods. The species Maribacter aquivivus and Maribacter sedimenticola were firstly reported as nitrate reducers (Nedashkovskaya et al., 2004). The type strain of Maribacter arcticus also reduces nitrate to nitrate (Cho et al., 2008). Strains KMM 6025 and KMM $6046^{\mathrm{T}}$ did not show the presence of nitrate reductase when the API 20NE gallery was used, but production of this enzyme was found by the method described by Gerhardt et al. (1994). This information is included in an emended description of the genus as proposed below.

\section{Emended description of the genus Maribacter Nedashkovskaya et al. 2004 emend. Barbeyron et al. 2008}

This description is based on that given by Nedashkovskaya et al. (2004) and Barbeyron et al. (2008) except that strains can reduce nitrate to nitrite. Arginine dihydrolase, lysine- and ornithine-decarboxylases and tryptophan deaminase activities are absent.

\section{Description of Maribacter stanieri sp. nov.}

Maribacter stanieri (sta'ni.er.i. N.L. gen. n. stanieri named in honour of the famous Canadian microbiologist Roger Y. Stanier for his great contribution to development of marine microbiology and, especially, to the investigation of the taxonomy and ecology of Cytophaga-like bacteria, currently the phylum Bacteroidetes).

Cells are strictly aerobic, heterotrophic, motile by gliding, Gram-negative, rod-shaped and $0.3-0.5 \mu \mathrm{m}$ wide and 2.4$5.3 \mu \mathrm{m}$ long. On marine agar, colonies are circular, yellow pigmented, shiny with entire edges and $2-4 \mathrm{~mm}$ in diameter. No flexirubin-type pigments are formed. Growth occurs with $0.5-8 \% \mathrm{NaCl}$, at $4-35{ }^{\circ} \mathrm{C}$ and at $\mathrm{pH}$ 5.5-10.0. Optimal growth is observed with $0.5-2 \%$ $\mathrm{NaCl}$, at $23-28{ }^{\circ} \mathrm{C}$ and at $\mathrm{pH} 7.0-7.5$. Oxidase, catalase, $\beta$-galactosidase and alkaline phosphatase activities are present. Decomposes aesculin, gelatin, Tweens 20 and 40 . 
Table 2. Phenotypic characteristics of species of the genus Maribacter

Species: 1, KMM 6025 and KMM 6046 ${ }^{\mathrm{T}}$; 2, Maribacter aquivivus; 3, Maribacter arcticus; 4, Maribacter dokdonensis; 5, Maribacter forsetii; 6, Maribacter orientalis; 7, Maribacter polysiphoniae; 8, Maribacter sedimenticola; 9, Maribacter ulvicola. All strains are positive for the following characteristics: respiratory metabolism; gliding motility and oxidase, catalase and alkaline phosphatase activities. All strains are negative for the following characteristics: production of flexirubin type pigments; hydrolysis of urea, CM-cellulose and chitin, and production of indole and $\mathrm{H}_{2} \mathrm{~S}$. Data from Barbeyron et al. (2008); Cho et al. (2008); Nedashkovskaya et al. (2004, 2007) and Yoon et al. (2005). W, Weakly positive reaction; $\mathrm{V}$, variable reaction; ND, not detected; + , positive; - , negative.

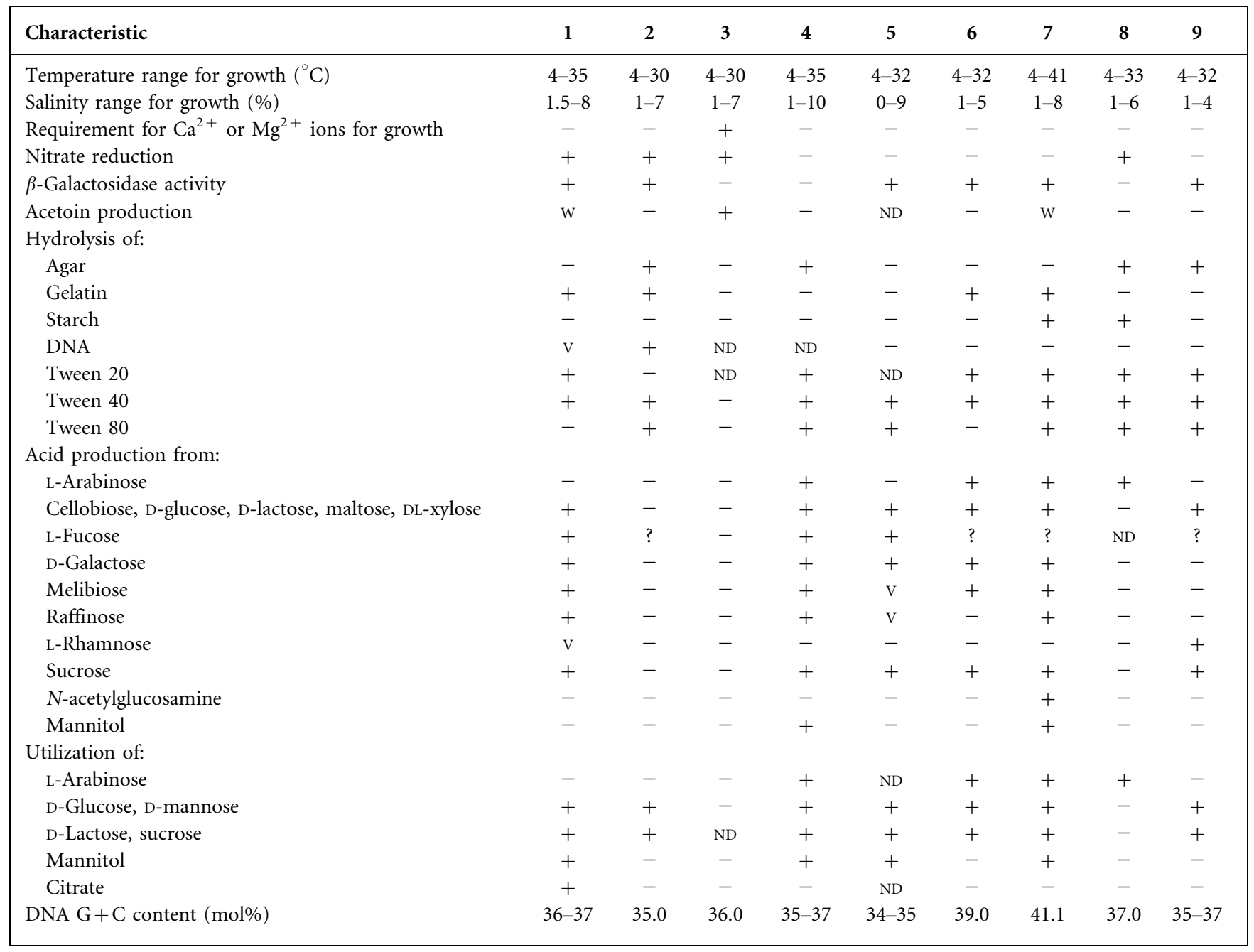

Does not hydrolyse agar, casein, starch, Tween 80, CMcellulose, urea or chitin. Hydrolysis of DNA is strainspecific. Produces acid from cellobiose, L-fucose, Dgalactose, D-glucose, D-lactose, maltose, melibiose, raffinose, sucrose, DL-xylose, but not from L-arabinose, $\mathrm{N}$ acetylglucosamine, citrate, adonitol, dulcitol, glycerol, inositol or mannitol. Oxidation of L-rhamnose is straindependent. Utilizes arabinose and mannose, but not inositol or sorbitol. According to the API 20NE gallery, mannitol, $N$-acetylglucosamine, malate, gluconate, adipate and citrate are also utilized. Testing by using API ZYM gallery indicated that the type strain produces esterase (C4), esterase lipase (C8), leucine arylamidase, valine arylamidase, trypsin, $\alpha$-chymotrypsin, acid phosphatase,
naphthol-AS-BI-phosphohydrolase, $\alpha$-galactosidase, $\alpha$ - and $\beta$-glucosidases, $N$-acetyl- $\beta$-glucosidase and $\alpha$-mannosidase activities, but lipase (C14), cystine arylamidase, $\beta$ glucuronidase and $\alpha$-fucosidase are absent. Nitrate is reduced. Acetoin (Voges-Proskauer reaction) is produced weakly, but $\mathrm{H}_{2} \mathrm{~S}$ and indole are not. Susceptible to carbenicillin, chloramphenicol, erythromycin, doxycycline, lincomycin, neomycin, oleandomycin, streptomycin and tetracycline, resistant to ampicillin, benzylpenicillin, gentamicin, kanamycin and polymixin. The predominant fatty acids are iso- $\mathrm{C}_{15: 1} \mathrm{G}$, iso- $\mathrm{C}_{15: 0}, \mathrm{C}_{15: 0}$, iso- $\mathrm{C}_{17: 1} \omega 9 c$, iso- $\mathrm{C}_{17: 0} 3-\mathrm{OH}$ and summed feature 3 , comprising $\mathrm{C}_{16: 1} \omega 7 c$ and/or iso- $\mathrm{C}_{15: 0}$ 2-OH. The DNA $\mathrm{G}+\mathrm{C}$ content is $36-37 \mathrm{~mol} \%$. 
The type strain, KMM $6046^{\mathrm{T}}\left(=\mathrm{KCTC} 22023^{\mathrm{T}}=\mathrm{LMG}\right.$ $22581^{\mathrm{T}}$ ), was isolated from the green alga Ulva fenestrata, collected in Troitsa Bay, Gulf of Peter the Great, Sea of Japan (also known as the East Sea).

\section{Acknowledgements}

This research was supported by grants from the State Contract 02.518.11.7169 from the Federal Agency for Science and Innovations of the Russian Federation, the Russian Foundation for Basic Research (RFBR) no. 09-04-00420 and Presidium of the Russian Academy of Sciences 'Molecular and Cell Biology'.

\section{References}

Agogué, H., Joux, F., Obernosterer, I. \& Lebaron, P. (2005). Resistance of marine bacterioneuston to solar radiation. Appl Environ Microbiol 71, 5282-5289.

Barbeyron, T., Carpenter, F., L'Haridon, S., Schüler, M., Michel, G. \& Amann, R. (2008). Description of Maribacter forsetii sp. nov., a marine Flavobacteriaceae isolated from North Sea water, and emended description of the genus Maribacter. Int J Syst Evol Microbiol 58, 790-797.

Bernardet, J.-F., Nakagawa, Y. \& Holmes, B. (2002). Proposed minimal standards for describing new taxa of the family Flavobacteriaceae and emended description of the family. Int J Syst Evol Microbiol 52, 1049-1070.

Cho, S. H., Han, J. H., Seong, C. N. \& Kim, S. B. (2006). Phylogenetic diversity of acidophilic sporoactinobacteria isolated from various soils. J Microbiol 44, 600-606.

Cho, K. H., Hong, S. G., Cho, H. H., Lee, Y. K., Chun, J. \& Lee, H. K. (2008). Maribacter arcticus sp. nov., isolated from Arctic marine sediment. Int J Syst Evol Microbiol 58, 1300-1303.

De Ley, J., Cattoir, H. \& Reynaerts, A. (1970). The quantitative measurement of DNA hybridization from renaturation rates. Eur $J$ Biochem 12, 133-142.

Felsenstein, J. (1993). PHYLIP (phylogeny inference package), version 3.5c. Distributed by the author. Department of Genome Sciences, University of Washington, Seattle, USA.

Gerhardt, P., Murray, R. G. E., Wood, W. A. \& Krieg, N. R. (editors) (1994). Methods for General and Molecular Bacteriology. Washington, DC: American Society for Microbiology.

Hamasaki, K., Taniguchi, A., Tada, Y., Long, R. A. \& Azam, F. (2007). Actively growing bacteria in the Inland Sea of Japan, identified by combined bromodeoxyuridine immunocapture and denaturing gradient gel electrophoresis. Appl Environ Microbiol 73, 2787-2798.

Kimura, M. (1980). A simple method for estimating evolutionary rates of base substitutions through comparative studies of nucleotide sequences. J Mol Evol 16, 111-120.

Kluge, A. G. \& Farris, J. S. (1969). Quantitative phyletics and the evolution of anurans. Syst Zool 18, 1-32.

Marmur, J. (1961). A procedure for the isolation of deoxyribonucleic acid from microorganisms. J Mol Biol 3, 208-218.

Marmur, J. \& Doty, P. (1962). Determination of the base composition of deoxyribonucleic acid from its thermal denaturation temperature. J Mol Biol 5, 109-118.

Nedashkovskaya, O. I., Kim, S. B., Han, S. K., Lysenko, A. M., Rohde, M., Rhee, M.-S., Frolova, G. M., Falsen, E., Mikhailov, V. V. \& Bae, K. S. (2004). Maribacter gen. nov., a new member of the family Flavobacteriaceae, isolated from marine habitats, containing the species Maribacter sedimenticola sp. nov., Maribacter aquivivus sp. nov., Maribacter orientalis sp. nov. and Maribacter ulvicola sp. nov. Int J Syst Evol Microbiol 54, 1017-1023.

Nedashkovskaya, O. I., Kim, S. B., Vancanneyt, M., Lysenko, A. M., Shin, D. S., Park, M. S., Lee, K. H., Jung, W. J., Kalinovskaya, N. I. \& other authors (2006). Echinicola pacifica gen. nov., sp. nov., a novel flexibacterium isolated from the sea urchin Strongylocentrotus intermedius. Int J Syst Evol Microbiol 56, 953-958.

Nedashkovskaya, O. I., Vancanneyt, M., De Vos, P., Kim, S. B., Lee, M. S. \& Mikhailov, V. V. (2007). Maribacter polysiphoniae sp. nov., isolated from a red alga. Int J Syst Evol Microbiol 57, 2840-2843.

Prabagaran, S. R., Manorama, R., Delille, D. \& Shivaji, S. (2007). Predominance of Roseobacter, Sulfitobacter, Glaciecola and Psychrobacter in seawater collected off Ushuaia, Argentina, SubAntarctica. FEMS Microbiol Ecol 59, 342-355.

Saitou, N. \& Nei, M. (1987). The neighbor-joining method: a new method for reconstructing phylogenetic trees. Mol Biol Evol 4, 406425.

Wayne, L. G., Brenner, D. J., Colwell, R. R., Grimont, P. A. D., Kandler, O., Krichevsky, M. I., Moore, L. H., Moore, W. E. C., Murray, R. G. E. \& other authors (1987). International Committee on Systematic Bacteriology. Report of the ad hoc committee on reconciliation of approaches to bacterial systematics. Int J Syst Bacteriol 37, 463-464.

Yoon, J. H., Kang, S.-J., Lee, S.-Y., Lee, C.-H. \& Oh, T.-K. (2005). Maribacter dokdonensis sp. nov., isolated from sea water off a Korean island, Dokdo. Int J Syst Evol Microbiol 55, 2051-2055. 